\title{
Clinical and laboratory studies in patients with leprosy and enthesitis
}

\author{
S L Atkin, A El-Ghobarey, M Kamel, J P Owen, W C Dick
}

\begin{abstract}
In a combined clinical, radiological, and laboratory study of 77 patients throughout the leprosy spectrum, 10 patients had an enthesitis which has not been described previously as far as is known and which was not associated with the characteristics of erythema nodosum leprosum reactions. $C$ reactive protein and $\alpha_{1}$ acid glycoprotein values were significantly lowered only in those patients with leprosy and enthesitis. No radiological abnormalities were found.
\end{abstract}

Charcot joints and the arthritis associated with erythema nodosum leprosum reactions are well recognised features of leprosy. ${ }^{12}$ Rarely has an arthritis mainly affecting the joints of the wrists, elbows, knees $^{3}$ and proximal joints ${ }^{4}$ been recorded. We have previously described a chronic peripheral polyarthritis in the absence of erythema nodosum leprosum reactions, throughout the leprosy spectrum, ${ }^{67}$ which was erosive in some patients. ${ }^{7}$ As far as we know, no studies have focused on the enthesis, the site of attachment to bone of tendon, ligament, or joint capsule.

In a study concentrating on the synovial joints of patients with active leprosy infection ${ }^{7}$ patients were examined clinically and radiologically for an enthesopathy.

\section{Patients and methods}

Seventy seven patients (49 men, 28 women) with a mean age of 35.6 (SEM 14.9) years and a mean duration of leprosy infection of $9 \cdot 6$ (SEM 7.6) years were studied (table 1 ). The sex ratio was 1.7 to 1 . All patients were seen in the Abou Zabel leprosy colony in Egypt. In every patient the diagnosis was based on clinical and histopathological features. ${ }^{8}$

Enthesitis was defined as tenderness to palpation at the site of attachment of bone to tendon, ligament, or joint capsule. At the beginning of the assessment a standard palpation over the anterior-superior aspects of the middle third of the clavicle (bilaterally) was used so that patients could compare and discriminate between pressure alone and tenderness over the entheses. ${ }^{9}$ Firm palpation over the sites of the entheses was used and scored either individually or as a group, the highest scoring site being recorded for the group as a whole. Sites grouped in this way were: the nuchal crests, the costochondral joints, the sacroiliac joints, and the cervical and lumbar spinous processes. The remaining sites were scored individually on both sides. ${ }^{9}$ Sites were scored as follows: $0=$ no pain; $1=$ mild tenderness; 2 =moderate tenderness; $3=$ wince or withdraw enthesitis.

The following sites of entheses were examined: the nuchal crests, the manubriosternal joint, the costochondral joints, the greater tuberosity and the medial and lateral epicondyles of the humerus, the iliac crests and the anterior iliac spines, the greater trochanter of the femur, the tibial tuberosities, the adductor tubercles, the medial and lateral condyles of the femur and tibia, the head of the fibula, the calcaneal insertions of the plantar fascia and the Achilles tendons, and the anterior posterior iliac spines. The enthesis index ${ }^{9}$ and the Ritchie articular index ${ }^{10}$ were recorded for all patients.

Patients with Charcot's arthropathy and those whose limbs were abnormal on clinical neurological examination were excluded from this study. A history or physical signs suggesting seronegative spondarthritides or recent systemic disturbance, especially gastrointestinal symptoms, also precluded entry into this study. Hepatitis B infection was excluded serologically.

\section{RADIOLOGY}

Standard views were taken of the hands, feet, knees, and spine. Radiographs were assessed by one radiologist (JPO) in the absence of the clinical and laboratory results. Only those patients with musculoskeletal symptoms were radiographed.

\section{LABORATORY TESTS}

Serum was separated and aliquots were transported on dry ice to the United Kingdom. $\alpha_{1}$ Acid glycoprotein, ${ }^{11} \alpha_{2}$ macroglobulin, ${ }^{11} \mathrm{C}$ reactive protein, ${ }^{12}$ and IgM rheumatoid factor ${ }^{13}$ were determined by established methods.

Non-parametric tests (Mann-Whitney U) were used to compare data between the clinical groups. ${ }^{14}$

\section{Results}

\section{CLINICAL FEATURES}

Ten patients had a generalised enthesitis (enthesis index range 10 to 70 ) (table 1 ).

Thirty three patients had uncomplicated leprosy, 20 patients had leprosy and the manifestations of an arthritis, and 14 patients had an erythema nodosum leprosum reaction as a complication of leprosy (table 1). The results for these patients are reported elsewhere. ${ }^{7}$

The history was that of an insidious development of pain and stiffness at the site of the 
Table 1 Data for all patients studied and those with enthesitis. Data are given as mean (SEM)

\begin{tabular}{lllll}
\hline $\begin{array}{l}\text { Leprosy } \\
\text { type* }\end{array}$ & $\begin{array}{l}\text { Number } \\
\text { of patients }\end{array}$ & $\begin{array}{l}\text { Sex } \\
(M: F)\end{array}$ & $\begin{array}{l}\text { Age } \\
\text { (years) }\end{array}$ & $\begin{array}{l}\text { Ducration of } \\
\text { disease (vears) }\end{array}$ \\
\hline LL & 37 & $22: 15$ & $36 \cdot 3(14 \cdot 7)$ & $10 \cdot 9(2 \cdot 5)$ \\
with enthesitis & 8 & $3: 5$ & $39 \cdot 7(5 \cdot 8)$ & $1 \cdot 6(4 \cdot 1)$ \\
BL & 9 & $7: 2$ & $33 \cdot 4(13 \cdot 4)$ & $7 \cdot 0(1 \cdot 4)$ \\
BB & 7 & $5: 2$ & $39 \cdot 3(16 \cdot 8)$ & $4 \cdot 5(2 \cdot 0)$ \\
BT & 5 & $3: 2$ & $33 \cdot 5(7 \cdot 7)$ & $6 \cdot 0(3 \cdot 1)$ \\
with enthesitis & 1 & F & 26 & 4 \\
TL & 4 & $2: 2$ & $41 \cdot 3(4 \cdot 2)$ & $25 \cdot 0(5 \cdot 0)$ \\
ENL & 14 & $9: 5$ & $28 \cdot 2(4 \cdot 2)$ & $9 \cdot 4(3 \cdot 8)$ \\
with enthesitis & 1 & $M$ & 55 & 40 \\
IDL & 1 & $M$ & 5 & $0 \cdot 5$
\end{tabular}

${ }^{*} \mathrm{LL}=$ lepromatous leprosy; $\mathrm{BL}=$ borderline lepromatous; $\mathrm{BB}=$ borderline; $\mathrm{BT}=$ borderline tuberculoid, $\mathrm{TL}=$ tuberculoid leprosy; $\mathrm{ENL}=$ erythema nodosum leprosum; IDL=indeterminate leprosy. musculoskeletal symptoms are given below. The values for the acute phase proteins were similar throughout the leprosy spectrum in those patients without musculoskeletal manifestations. Patients with leprosy and enthesitis were compared with those patients with leprosy alone.

C reactive protein (mean $4 \cdot 2(\mathrm{SEM} 2 \cdot 4) \mathrm{mg} / \mathrm{l}$, $\mathrm{p}<0.05)$ and $\alpha_{1}$ acid glycoprotein concentrations (712 (77) $\mathrm{mg} / \mathrm{l}, \mathrm{p}<0.01$ ) were reduced significantly compared with patients with leprosy alone (CRP 15 (4.5) $\mathrm{mg} / \mathrm{l} ; \alpha_{1}$ acid glycoprotein $823(65) \mathrm{mg} / \mathrm{l}) . \alpha_{2}$ Macroglobulin concentrations (2667 (145) mg/l, p<0.340) did not differ significantly from those of patients with leprosy without an enthesitis $(2788$ (170) $\mathrm{mg} / \mathrm{l})$.

enthesis, presenting months or years after the onset of the first symptoms of leprosy. Pain at the site of the enthesis seemed to have no temporal correlation with type 1 or type 2 lepra reactions, nor were there any coincident features of either of these reactions. The pattern was one of chronic exacerbations and remissions, with no specific evolution, symmetry, or pattern of disease of any single enthesis or groups of entheses either centrally or peripherally. The only consistent feature was that the number of entheses affected at any one time was never less than five. Morning stiffness lasted variably for between 15 minutes and one hour and inactivity stiffness ('gelling') varied between 10 and 15 minutes.

Synovial proliferation was not detected, nor was there clinical evidence for an underlying vasculitis. Subcutaneous or tendinous nodules, and other extra-articular manifestations of the seronegative spondarthritides ${ }^{15}$ or rheumatoid arthritis were not detected. The symptoms and signs of the enthesopathy in the patient with the supervening erythema nodosum leprosum reaction remained unchanged during and after the reaction.

No patient with arthritis had concurrent enthesitis and no patient with an enthesitis had arthritis at that time or previously.

No radiological abnormalities were found around any of the affected entheses nor in the three available sacroiliac joint radiographs in this patient group.

\section{LABORATORY RESULTS}

Table 2 summarises the results of the RoseWaaler test to detect the presence of IgM rheumatoid factor.

The acute phase protein values of those patients with leprosy with and without arthritis are reported elsewhere, ${ }^{7}$ but for clarity the values for the patients with leprosy without

Table 2 Rose-Waaler results found in patients with leprosy alone and in patients with leprosy with arthritis or enthesitis or erythema nodosum leprosum (ENL) reactions

\begin{tabular}{llllc}
\hline Titre & $\begin{array}{l}\text { ENL } \\
(n=14)\end{array}$ & $\begin{array}{l}\text { Anthritis } \\
(n=20)\end{array}$ & $\begin{array}{l}\text { Enthesitis } \\
(n=10)\end{array}$ & $\begin{array}{l}\text { Leprosy } \\
(n=33)\end{array}$ \\
\hline $1 / 32$ & 2 & 4 & 1 & 5 \\
$1 / 64$ & 1 & 1 & 0 & 7 \\
$11 / 128$ & 1 & 3 & 1 & 9 \\
$1 / 1024$ & 0 & 0 & 0 & 1 \\
Total positive & 4 & 8 & 2 & 22 \\
\hline
\end{tabular}

\section{Discussion}

As far as we know, the enthesopathy described in this study has not been reported before in patients with leprosy. A few studies have focused on the musculoskeletal aspects of leprosy $^{1-7}$ but none on the systematic examination of the entheses. This may be because there has been no validated protocol reported until recently. ${ }^{9}$ The enthesitis described here was not localised to any specific site in any specific pattern, nor was it associated with past or present symptoms of an arthritis. This suggests that different mechanisms may be responsible for the musculoskeletal manifestations in leprosy, rather than there being a spectrum of symptoms and signs.

The most common cause for an isolated lesion at the enthesis is trauma. Inflammatory disease at several entheses raises the possibility that one of the seronegative spondarthritides might have been responsible, but absence of evidence in the past history, family history, clinical presentation, and examination, supported by normal sacroiliac joint radiographs in three patients, make this unlikely. The overt manifestations of the seronegative spondarthritides may not present for many years, however, making it difficult to refute this suggestion entirely.

The incidence of IgM rheumatoid factor is often high in Third World countries and in patients with leprosy. ${ }^{16} 17$ In this study two of $10(20 \%)$ patients with leprosy and enthesitis had a positive IgM rheumatoid factor in their serum compared with 22 of $33(66 \%)$ patients with leprosy without any musculoskeletal problems. The number of patients with an enthesitis is too small, however, to determine whether there is an association with IgM rheumatoid factor. Although rheumatoid arthritis cannot be excluded, no patient with an enthesitis was suffering from an arthritis or clinically apparent vasculitis. The large number of patients, the predominance of men, and the lack of extra-articular manifestations of rheumatoid arthritis also make this possibility unlikely.

All but one patient had lepromatous leprosy. Possibly, this enthesitis is a manifestation of chronic erythema nodosum leprosum. The lack of a temporal correlation with erythema nodosum leprosum and the absence of clinical signs of that lepra reaction suggest that this is not the case. 
$\alpha_{2}$ Macroglobulin and $\alpha_{1}$ acid glycoprotein bind and transport potentially destructive enzymes released at the site of tissue destruction. ${ }^{18} \mathrm{C}$ reactive protein concentration rises in response to any chronic inflammatory disease affecting the synovial joint ${ }^{19}$ and may rise particularly steeply in response to tissue damage by bacteria rather than by other agents. A significant fall in $\alpha_{1}$ acid glycoprotein concentrations has been noted in other causes of an infective enthesitis, suggesting its increased consumption. $^{20}$ In this case, however, an increase in $\mathrm{C}$ reactive protein would be expected, as seen in patients with leprosy and arthritis, ${ }^{2} 67$ rather than a decrease as we report here. An alternative explanation is reduced synthesis of both reactants.

Owing to the isolated environment of the leprosy colony no details of the incidence or prevalence of an enthesitis in patients with leprosy is available. This study highlights the possibility that an enthesitis may be a facet of leprosy infection and that significantly low concentrations of $\alpha_{1}$ acid glycoprotein and C reactive protein may mark the enthesitis in patients with leprosy.

We wish to thank Dr Constable of the Royal Victoria Infirmary, Newcastle upon Tyne for his support and advice. This study could not have taken place without the support of LEPRA and could not have taken place without the support of LEPRA and
that of the Arthritis and Rheumatism Council (Great Britain), to which we are indebted.

1 Karat A B A, Karat S, Job C K. Acute exudative arthritis in leprosy: rheumatoid-like syndrome in association with erythema nodosum leprosum. $\mathrm{Br}$ Med $\mathcal{F}$ 1966; iii: 770-3.

2 Ramu G, Balakrishnan S. Arthritis in lepromatous leprosy: clinical features and

Alcocer J V, Herrera C L, Gudino J, Fraga A. Inflammatory arthropathy in leprosy [Abstract]. Arthritis Rheum 1979; 22: 597.

4 Lele R D, Sainani G S, Sharma K D. Leprosy presenting as rheuma

$$
\text { 275-7. }
$$

5 Modi T H Lele R D. Acute joint manifestations in leprosy. f Assoc Physicians India 1969; 17: 247-54.

6 Atkin S L, Welbury R R, Stanfield E, Beavis D, Iwais B Dick W C. Clinical and laboratory studies of inflammatory polyarthritis in patients with leprosy in Papua New Guinea. Ann Rhewen Dis 1987; 46: 688-90.

7 Atkin S L, El-Ghobarey A, Kamel M, Owen J P, Dick W C Clinical and laboratory studies of arthritis in leprosy. $B$ Med J 1989; 298: 1423-5.

8 Ridley D S, Jopling W H. Classification of leprosy according to immunity: a five group system. International foumal of Leprosy 1966; 34: 255-73.

9 Mander M Simpson J M, McLellan A, Walker D, Goodacre J A, Dick W C. Studies with an enthesis index as a method of , Dick W C. Studies with an enthesis index as a method of clinical assessment in

10 Ritchie D M, Boyle J A, McInnes J M, et al. Clinical studies with an articular index for the assessment of joint tenderness in patients with rheumatoid arthritis. $Q \mathcal{F}$ Med 1968 37: 393-406.

11 Deaton C D, Maxwell K W, Smith R S, Crevelling R L. Use of laser nephelometry in the measurement of serum proteins. Clin Chem 1975; 22: 1465-9.

12 Rubinstein K E, Schneider R S, Ullman E F. "Homogeneous" enzyme immunoassay: a new immunochemical technique. Biochem Biophys Res Commun 1972; 47: 846-51.

13 Waler E. On the occurrence of a factor in human serum activating the specific agglutination of sheep red corpuscles. activating the specific agglutination of sheep red corpuscles. Acta $P$

14 Nie N H, Hull C H, Jenkins J G, Steinbrenner K, Bent D H. SSPS; statistical package for the social sciences. New York: McGraw-Hill, 1975 .

15 Wright V. Relationship between ankylosing spondylitis and other spondarthritides. In: Moll J M A ed. Ankylosing spondylitis. London: Churchill Livingstone, 1980: 42-52.

16 Cathcart E S, Williams R C, Ross S H, et al. The relationship of the latex fixation test to the clinical and serological manifestations of leprosy. Am 7 Med 1962; 56: 545-52.

17 Gonzales-Pares E N, Franco A E, De La Cruz S, Molares F R, Gonzales-Alcover R, Bryan R M. False positive latex in a tropical area. $f$ Chronic Dis 1973; 26: 31-8.

$18 \mathrm{Koj} \mathrm{A.} \mathrm{Acute} \mathrm{phase} \mathrm{reactants.} \mathrm{In:} \mathrm{Allison} \mathrm{A} \mathrm{C,} \mathrm{ed.} \mathrm{Structure}$ Koj A. Acute phase reactants. In: Allison A C, ed. Structure 1974: 73-125.

19 Carr W. Acute phase proteins. In: Jeffery M S, Dick W C, eds. The role of the laboratory. London: Saunders, 1983: 227-339.

20 Becker G J, Walberg M, Hughes G R V, Pepys M B. Value of C-reactive protein measurement in the investigation of fever in systemic lupus erythematosus. Ann Rherem $D$ is 1980 39: 50-2. 